REVIEW

\title{
The Burden of Bancroftian Filariasis in Nigeria: A Review
}

\author{
Adamu Hussaini ${ }^{1 *}$, Clement Isaac ${ }^{1}$, Hussaini Rahimat ${ }^{1}$, Inegbenosun Collins ${ }^{1}$, \\ Obasuyi Cedric ${ }^{2}$, Ezekiel Solomon ${ }^{1}$
}

\footnotetext{
OPEN ACCESS

Citation: Adamu Hussaini, Clement Isaac, Hussaini Rahimat, Inegbenosun Collins, Obasuyi Cedric, Ezekiel Solomon. The Burden of Bancroftian Filariasis in Nigeria: A Review. Ethiop J Health Sci.2020;30(2):301.doi:http://dx. doi.org/10.4314/ejhs.v30 i2.18

Received: August 18, 2019

Accepted: October 31, 2019

Published: March 1, 2020

Copyright: (C)2020 Adamu H., et al. This is an open access article distributed under the terms of the Creative Commons Attribution License, which permits unrestricted use, distribution, and reproduction in any medium, provided the original author and source are credited. Funding: Nil. Competing Interests: The authors declare that this manuscript was approved by all authors in its form and that no competing interest exists. Affiliation and Correspondence:

${ }^{1}$ Department of Zoology, Faculty of

Life Sciences, Ambrose Alli

University, Ekpoma, Nigeria.

${ }^{2}$ Department of Microbiology, Faculty

of Life Sciences, University of Benin,

Nigeria.

*Email: ojagefuadams@gmail.com
}

\section{ABSTRACT}

BACKGROUND: Lymphatic filariasis (LF) is a neglected tropical disease (NTD) vectored by mosquito; and people in rural areas are mostly at risk of infection. Pooling prevalence data across the six geo-political zones of Nigeria is expected to provide a clearer insight into the burden of the disease as this information could guide towards planning eradication programmes.

METHODS: Search for pertinent literature was done on Google Scholar, African Journal Online (AJOL) and PubMed databases using relevant keywords. Studies on the prevalence of $L F$ due to Wuchereria bancrofti in Nigeria were selected and reviewed. Prevalence data from the different states were further organized into the six geopolitical zones and analyzed.

RESULTS: Of the 36 states in Nigeria, prevalence data were available only for 19 states. Furthermore, in the six geopolitical zones, North-West had the highest disease burden (44 per 10 000) of Years Lived with Disability (YLD), while North-Central (4 per 10 000) had the lowest disease burden.

CONCLUSION: Result are largely attributed to the prevailing conditions in the different zones. In view of ensuring a successful control plan and eventual eradication of the disease, a comprehensive national survey in every state should be carried out using more sensitive tools.

KEYWORDS: Lymphatic filariasis, Wuchereria bancrofti, YLD, Nigeria

\section{INTRODUCTION}

Wuchereria bancrofti vectored by mosquitoes is a human parasitic filarial round worm responsible for the disease-lymphatic filariasis (LF) (1). Of note, is the fact that Wucheriria bancrofti is more prevalent than filariasis from Brugia malayi and Brugia timori, as infection could advance to a chronic stage like elephantiasis of the extremities and genitals (1).

In sub-Saharan Africa, 512 million people are at risk of being infected, while 28 million are known to be infected (2). Although mortality from LF is low, the disease is the fourth leading cause of Disability Adjusted Life Years (DALYs) $(2,3)$. 
Nigeria is ranked the third most endemic country globally; and in the past, studies on the disease distribution were classified based on the disease prevalence at national or sub-national levels with no account for geopolitical zones heterogeneity (4). Therefore, such estimates did not accurately capture LF burden at zonal levels (5). Analyzing data at geopolitical/zonal level would provide more detailed report on the dynamics of the disease in a way that the disease prevalence and burden could be mapped and as such guide on control strategy. This review article thus presents prevalence data of LF from endemic areas in Nigeria and highlights the gaps in knowledge.

\section{CASE DETAILS}

LF, after malaria happens to be the second most common vector-borne parasitic diseases; and it is present in over 80 tropical and subtropical countries (6). According to WHO, LF ranks second as the common cause of long-term disability after mental illness $(6,7)$. LF is of global recognition, playing a significant role in the overall Africa disease burden. Furthermore, one-third of infected persons live in India, a third live in Africa and the remainder in the Americas, the Pacific Island, Papua New Guinea and South-East Asia (8). Persons with LF and other helminthic diseases particularly women and children become more susceptible to secondary infection with HIV/AIDS, tuberculosis and malaria (2). LF is known to cause a wide range of clinical and subclinical symptoms. It is estimated that two-thirds of infected individuals present no obvious proof of the disease, but when tested, they showed some level of immunosuppression. In addition, there could be evidence of renal dysfunction, chronic lymphoedema, elephantiasis and hydrocele.

Evidence of debilitating effect of acute filarial attacks that have been said to last from five to seven days and may occur two to three times each year have been associated with sufferers of LF
$(6,7)$. Chronic filarial disease appears to correlate with serious social and economic burden as those afflicted with elephantiasis and hydrocele are often socially marginalized and are poor based on the severity of disease (9). Episodes of acute attack and chronic disability reduce economic output and increase poverty (6). Due to stigmatization, affected individuals avoid seeking treatment, and this result in the reoccurrence of acute febrile attacks and subsequent damage to the lymphatic system $(9,10)$. Infected women bear double burden as young unmarried women could be forced to live a secluded life and thus limit the prospect of marriage.

More so, recurrent debilitating acute episodes hinder their ability to be gainfully employed. Consequently, the cost of health care as well as other needs make them financially dependent on other people $(11,12)$. In West Africa and Thailand, there is a general believe that children born to women affected by LF would bear similar disease burden $(2,13)$. Shame and fear are associated with difficulties in conceiving, and these feelings are peculiar to LF patients globally (14). Meanwhile, women may have concerns about marrying men with physical sign of LF; their gender expectation and prevailing power strata often leave them in hopeless situations. In Haiti and Ghana, researchers alluded to the point that the risk of unhappiness and marriage breakdown was greater in marriages where the wife had physical signs of filariasis $(11,15)$.

In Nigeria, LF is widespread and it is a serious public health problem (1). Of the 36 states, LF studies were available for nineteen states (19) (Table 1). These studies spanned through the different geo-political zones (North-West, NorthEast, North-Central, South-West, South-East and South-South) of the country., However, there is still limited/lack of literature on the prevalence of LF disease in some other states. 
Table 1. Prevalence of Lymphatic filariasis across Zones and State.

\begin{tabular}{|c|c|c|c|c|c|c|}
\hline Zones & States & $\begin{array}{l}\text { Sample } \\
\text { size }\end{array}$ & $\begin{array}{l}\text { Diagnostic } \\
\text { techniques }\end{array}$ & $\begin{array}{l}\text { Prevalence } \\
(\%)\end{array}$ & Study population & Reference \\
\hline \multirow[t]{6}{*}{ North-West } & Kano & 2790 & Blood smear & 1.7 & Men and Women & [21] \\
\hline & Kano & 357 & Blood smear & 3.6 & Indigens of Kano & [41] \\
\hline & Kano & 54943 & Hydrocelectomy & 2.31 & Indigens of Kano & [42] \\
\hline & Kaduna & 793 & cases & 7.4 & Indigens of Kaduna & [43] \\
\hline & Kaduna & 341 & DEC provocation & 2.9 & Men and Women & [44] \\
\hline & Zamfara & 501 & $\begin{array}{l}\text { ICT Card test } \\
\text { RDT kit }\end{array}$ & 38.7 & Men and Women & [22] \\
\hline \multirow[t]{5}{*}{ North-East } & Bauchi & 1628 & Incubation & 1.4 & Men and Women & [45] \\
\hline & Taraba & 336 & ICT Card test & 30.05 & Indigens of Taraba & [46] \\
\hline & Taraba & 458 & Blood smear & 33.84 & Men and Women & [47] \\
\hline & Taraba & 327 & Blood smear & 30.8 & Indigens of Taraba & [48] \\
\hline & Taraba & 1031 & Blood smear & 21.2 & Children and Adults & [49] \\
\hline North- & Benue & 248 & ICT Card test & 32.6 & Indigens of Benue & {$[50]$} \\
\hline \multirow[t]{3}{*}{ Central } & Kogi & 1069 & ICT Card test & 3.4 & Male and Female & [51] \\
\hline & Plateau & 7250 & Clinical examination & 0.4 & Men and Women & {$[52]$} \\
\hline & Plateau & 940 & Blood smear & 1.8 & Men and Women & [53] \\
\hline \multirow[t]{7}{*}{ South-West } & Ogun & 500 & Blood smear & 21.0 & Children and Adults & [54] \\
\hline & Ogun & 317 & Blood smear & 17 & Children and Adults & {$[55]$} \\
\hline & Ogun & 587 & Blood smear & 3.2 & Children and Adults & {$[56]$} \\
\hline & Ondo & 231 & ICT Card test & 29 & Adolescent & [57] \\
\hline & Ondo & 1090 & ICT Card test & 27 & Children and Adults & [58] \\
\hline & Osun & 870 & ICT Card test & 1.7 & Children and Adults & [59] \\
\hline & Oyо & 95 & Physical examination & 26.3 & Indigens of Oyo & {$[60]$} \\
\hline \multirow[t]{6}{*}{ South-East } & Abia & 498 & Blood smear & 22.3 & Indigens of Abia & [61] \\
\hline & Ebonyi & 1243 & Blood smear & 16.9 & Children and Adults & [1] \\
\hline & Ebonyi & 600 & ICT Card test & 23.50 & Indigens of Ebonyi & [62] \\
\hline & Ebonyi & 425 & Clinical examination & 8.23 & Men and Women & [63] \\
\hline & Imo & 200 & Blood smear & 20 & Men and Women & [64] \\
\hline & Imo & 845 & Blood smear & 8.9 & Children and Adults & [65] \\
\hline South- & Akwa-Ibom & 400 & Concentration & 3.5 & Children and Adults & [66] \\
\hline \multirow[t]{5}{*}{ South } & Bayelsa & 78 & Concentration & 10.5 & Children and Adults & [67] \\
\hline & Cross-River & 897 & Blood smear & 15.5 & Children and Adults & [68] \\
\hline & Cross-River & 785 & Blood smear & 6.1 & Children and Adults & [69] \\
\hline & Cross-River & 829 & Blood smear & 5.5 & Children and Adults & {$[70]$} \\
\hline & Rivers & 1351 & Blood smear & 3.3 & Children and Adults & [18] \\
\hline
\end{tabular}

Cases of high prevalence of LF due to Wuchereria bancrofti have been reported with infection rates ranging between $9.1 \%$ and $18.8 \%$ in the eastern region and northern region respectively (16). Mbah and $\mathrm{Njoku}(17)$ reported a prevalence rate of $18.8 \%$ in Anambra State. Udonosi (18) observed prevalence rates of $8.7 \%, 11.8 \%$ and $14.9-25.6 \%$ in Imo and Rivers States respectively. Co-endemicity of Wuchereria bancrofti, Loa loa, Onchercerca volvulus with Mansonella perstans had a prevalence rate of $21.21 \%$ in Rivers and Bayelsa States (18). Furthermore, Braide et al (19) reported 13 cases of LF in Cross Rivers State. Amadi and Udonosi (20) also reported a prevalence rate of $4.4 \%$ in Ogoniland, Rivers State. Recently, Dogara et al (21a) reported a prevalence rate of $30.2 \%$ in Kano. More recently, Ladan et al (22) in his studies on the seroprevalence of LF in six communities of Bungudu Local Government Area of Zamfara State reported a prevalence rate of $38.72 \%$. The 
prevalence data in North-East, North-West and South-West is largely unknown (Figure 1).

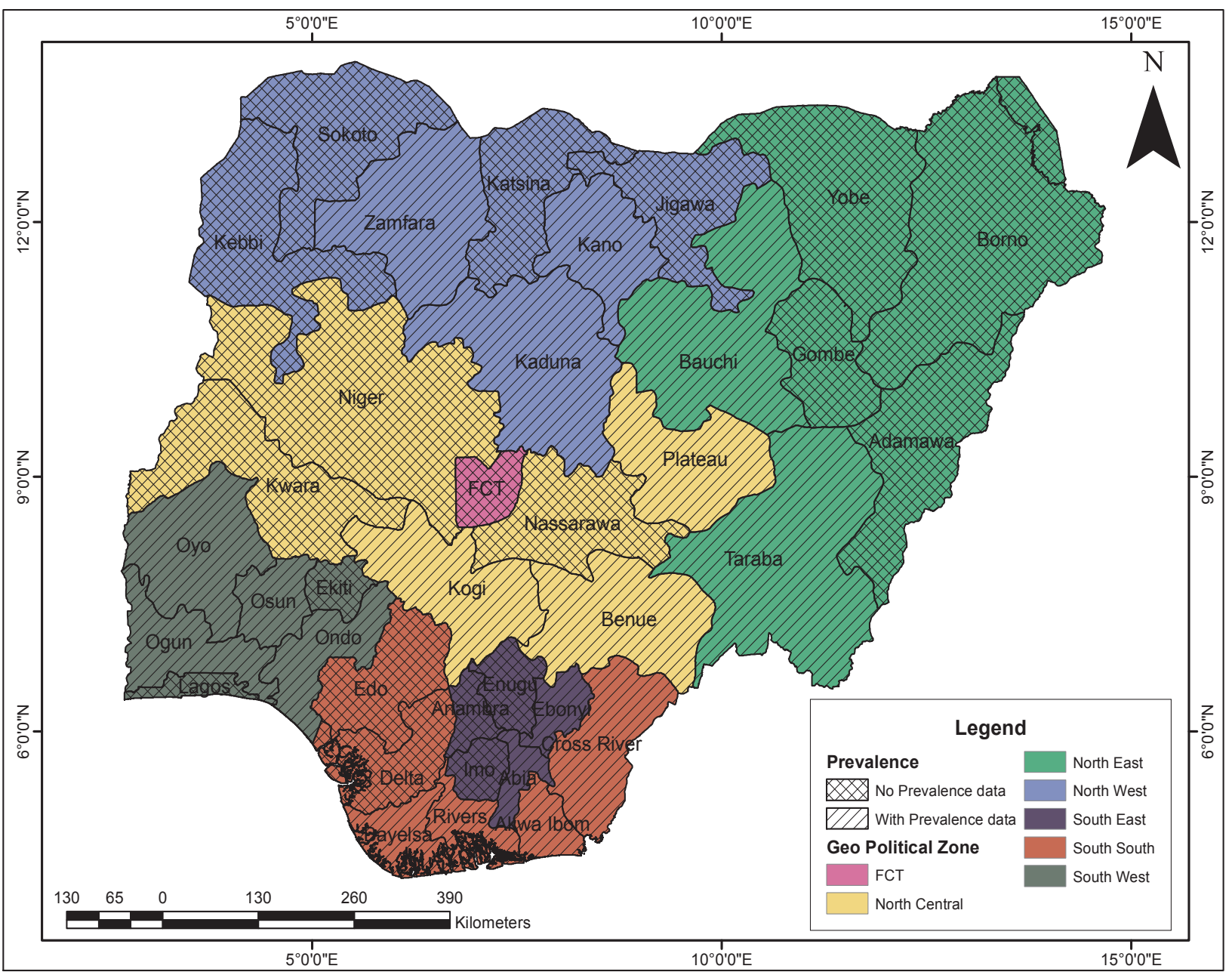

Figure 1: Prevalence data for Wucheriria bancrofti in the six geopolitical zones of Nigeria.

LF has impacted negatively on marriage and sexual life in endemic areas. Stigmatization of men with hydrocoele is also observed in some of the endemic countries as villagers in some parts of Nigeria discontinues association from people with filarial skin lesions and men with genital complications and elephantiasis (3). Furthermore, of the 128 million people estimated to be infected worldwide $(11,23,24), 22$ million $(17.2 \%)$ are children (school-aged) below the age of 15. LF ranks the second leading cause of long-term disability (7). More so, it has been linked with serious impairment of mobility (25), affecting school-aged children's education and future career prospects due to regular absenteeism from school (26). The affected children become frustrated to the point that they abandon their education and future endeavors (27).

Poor response of victims to submit themselves for examination and refusal to give night blood samples are challenges against the effective study of LF in Nigeria (20). Environmental factors and conditions influencing LF transmission are similar to those existing elsewhere in the tropics and other sub-Saharan African countries. Factors such as rural to urban migration, increasing urbanization, inadequate waste disposal and deteriorating sanitary conditions in the country could increase the number of breeding sites for the mosquito vectors (28). The roles of mosquitoes and other 
dipterans in transmitting the parasitic agents of filariasis are poorly acknowledged in many endemic communities. Therefore, it is surprising that there is little awareness on the need to minimize mosquito contact. Vectors like Culex papiens quinquefasciatus are distributed across the tropics and warm temperate regions and are believed to be indigenous to the low lands of West Africa. These vectors have reached the new world through slave ships; meanwhile an alternate hypothesis suggest it originates in Southeast Asia (29). Culex papiens quinquefasciatus are found in association with other mosquitoes' species in domestic and peri domestic water containers (30). Breeding takes place in eutrophic water of artificial containers or man-made impoundments like ditches, ponds, drains with high nutrient containing human or animal sewage (30). Factors such as adequate rainfall and longevity of the female C.p. quinquefasciastus have been attributed to survival and reproduction. With distinct rainy season, their population reaches its peak densities during or immediately after the rainy season, while in subtropical and warm temperate areas, peak populations occur during the warmest month of the year (30). Stomoxys species is a filth fly with worldwide medical and veterinary importance. There are 18 known species in the genus Stomoxys. Stomoxys calcitran is the only species that is synanthropic and present worldwide. Stomoxys species breeds in moist, decaying organic matter, while suitable environmental conditions like temperature of $27^{\circ} \mathrm{C}$, availability of host for blood meal, influence their survival and reproduction (31). Some of these associated agents that contribute to spread of the disease increase the disease burden, and hence, impacting positively on the spread of the disease.

There are many diagnostic methods available for the detection of LF. Until the 1980s, the only direct method to ascertain a diagnosis of infection by $W$. bancrofti was via the identification of microfilariae (MF) in the peripheral blood using camera counting, polycarbonate membrane filtration, the thick smear method or Knott's technique (32). Meanwhile, apart from their relatively low sensitivities, these methods only identify filarial infection by way of microfilaremia.
In the 1990s, significant improvements were made in the diagnosis of LF with the emergence of new diagnostic tools; namely, use of recombinant antigens to detect specific antibodies (33), PCR for the detection of filarial DNA, the visualization of live adult worms (AW) using ultrasound (US) and circulating filarial antigen (CFA) detection (34). Presently, the standard diagnostic tools are US (34) and CFA detection technique, with the latter using the monoclonal antibodies (McAbs) $\mathrm{Og} 4 \mathrm{C} 3$ and AD12. Meanwhile, the CFA detection techniques are commercially available in the form of kits with the advantage of ensuring the possibility of diagnosis using blood samples collected at any time of the day $(34,35)$. However, in Nigeria, there is no report of the use of molecular diagnostic tools for LF infection; therefore, we believe that the prevalence estimates presented in this report is significantly underestimated.

\section{DISCUSSION}

In drafting a cost-effective control for diseases, it is paramount that the disease burden be estimated. Disability Adjusted Life Year (DALYs) has become fast increasing metric measurement to assess disease burden (36). DALYs include years of life lost due to mortality (YLLs) and years lived with disability (YLDs). Reports of LF infection burden measured in DALYs are unavailable. Here, we have estimated the value of YLD (Table 2) based on the available prevalence data and morbidity of the infection (37). YLD due to LF in this review was estimated using this formula (38): $\mathrm{YLD}=\mathrm{P} \times \mathrm{DW}$; Where $\mathrm{P}=$ number of prevalence cases, DW=Disability Weight.

Furthermore, prevalence was used rather than incidence (38), because in Nigeria, surveys are widely reported in prevalence (Table 1). However, DW (0.027) of infection which is represented on a scale of $0-1 \quad(0=$ perfect health; $1=$ death $)$, was adopted (39). YLDs due to LF, according to the geo-political zones are shown in Table 2. This review shows that the YLD from LF prevalence data in Nigeria ranged from 4.0 to 44.0 with the highest and least disease burdens recorded in North-West and North-Central respectively. 
Table 2. Lymphatic filariasis mean prevalence and estimated YLD according to geopolitical zones (19822018).

\begin{tabular}{lll}
\hline Region & Mean \pm SD $(\%)$ & YLD per 10000 \\
\hline North-West & $9.4 \pm 14.5$ & 44.0 \\
North-East & $23.5 \pm 13.3$ & 16.0 \\
North-Central & $9.6 \pm 15.4$ & 4.0 \\
South-West & $17.9 \pm 11.3$ & 16.0 \\
South-East & $16.6 \pm 6.6$ & 17.0 \\
South-South & $7.4 \pm 4.7$ & 10.0 \\
\hline
\end{tabular}

Control and elimination rely largely on chemotherapy through mass drug administration (MDA) to interrupt transmission of infection (40). Drugs commonly administered against LF in Nigeria are diethylcarbamazine (DEC), Albendazole and ivermectin. Studies based on selective treatment with single dose of DEC $(6 \mathrm{mg} / \mathrm{kg})$ have been reported to decrease MF by $90 \%$ and adult by $50 \%$ (40). Furthermore, vector control methods such as the use of insecticides treated mosquito nets, indoor residual spraying as well as environmental sanitation would reduce the vector population and consequently the transmission of the disease. The YLD data in this report has clearly described the national situation and thus call for the need to intensify surveillance and treatment across all strata. LF control in Nigeria should especially be of high priority in the North-West.

The data in this review have highlighted LF prevalence in Nigeria, with North-West having the highest disease burden. The high prevalence in the North-West is largely attributed to unfavorable climatic conditions that threw up man-made options like construction of irrigation, thereby further enhancing the disease vectors to thrive. It is recommended that LF survey be carried out in states where prevalence data are yet to be available, so that a proper and more comprehensive evaluation of the LF situation in Nigeria be done to the extent that the most effective control strategy can be adopted and applied. Furthermore, to have a near-accurate picture of the prevalence of the disease, a more sensitive diagnostic method should be employed.

\section{REFERENCES}

1. Anosike JC, Nwoke BE, Ajayi EG, Onwuliri OU, Oku EE, Asor JE, Amajuoyi OU, Ikpeama AC, Ogbusu FI and Meribe CO. Lymphaticfilariasis among the Ezza people of Ebonyi state, Eastern Nigeria. Ann.Agric Environ. Med. 2005: 12,181-186.

2. WHO. Lymphatic filariasis: The disease and its control. Fifth report of the WHO expert committee on filariasis, Geneva; 2002.

3. Nwoke BEB, Mberu BU, Oha O, Dozie INS and Ukaga $\mathrm{CN}$. Lymphatic filariasis and Onchocerciasis in rain forest of southern Nigeria I. Clinical and parasitological studies; $2000 \mathrm{WHO} / \mathrm{TDR} / \mathrm{ID}: 981087$. WHO Geneva.

4. Cano J, Rebollo MP, Golding N, Pullan RL, Crellen $\mathrm{T}$ and Soler A: The global distribution and transmission limits of lymphatic filariasis: past and present. Parasit Vectors. 2014: 7, 466.

5. Gyapong JO, Kyelem D, Kleinschmidt I, Agbo K, Ahouandogbo F and Gaba J. The use of spatial analysis in mapping the distribution of bancroftian filariasis in four West Africa countries. Ann. Trop. Med. Parasitol. 2002; 96, 695-705.

6. Ottesen EA. The global programme to eliminate lymphatic filariasis. Trop.Med.Int.Health. 2000:5, 591-594.

7. Ottesen EA, Duke BOL, Karam M and Behbehani K. Strategies and tools for the control/elimination of lymphatic filariasis. Bull World Health Organ. 1997: 75, 491-503.

8. Molyneux DH, Hotez PJ, Fenwick A. "Rapidimpact interventions": how a policy of integrated control for Africa's neglected 
tropical disease could benefit the poor. PloSMed. 2005: 2, e336

9. Mujinja PGM, Gasarasi DB, Premiji ZG and Nguma J. Social and economic impact of lymphatic filariasis in Rufiji district, Southeast Tanzania. In: Lymphatic filariasis research and control in Africa. Report on a Workshop held in Tanga, Tanzania. Tanzania: Danish Bilharziasis Laboratory, Denmark and National institute for Medical research; 1997

10. Rauyajin O, Kamthornwachara B and Yablo P. Socio-cultural and behavioural aspects of mosquito borne lymphatic filariasis in Thailand: a qualitative analysis. Soc.Sci.Med. 1995:41, 1705-1713.

11. Gyapong M, Gyapong JO, Adjei S, Vlassoff C and Weiss M: Filariasis in Northern Ghana. Some cultural beliefs and practices and their implication for disease control. Soc.Sci.Med. 1996; 43, 235-242.

12. Kumari AK, Harichandrakumar KT, Das KL and Krishnamoorthy K. Physical and psychosocial burden due to lymphatic filariasis as perceived by patients and medical experts. Trop.Med.Int.Health. 2005; 10, 567573.

13. Amazigo UO and Obikeze DS. Social consequences of onchocercal skin lesions on adolescent girls in rural Nigeria. WHO/TDR Dicussion paper. Geneva:WHO; 1992.

14. Kessel JF. Disabling effects and control of filariasis. AM.J.Trop.Med.Hyg. 1957; 6, 402414.

15. Coreil J, Mayard G, Louis-Charles J and Addiss D. Filarial elephantiasis among Haitian women: social context and behavioural factors in treatment. Trop.med.Int.Health. 1998; 3, 467-473.

16. Badaki JA, Akogun OB and Akoh JI. The effect of low dose of Ivermectin on the emergence of Wucherirabancroftiin diurnal blood. Nigeria Journal of Parasitology. 1999: 20, 83-89.

17. Mbah DC and Njoku OO. Prevalence of Lymphatic filariasis in Oraeri, Anambra State, Nigeria. Journal of Parasitology. 2000: 21, 95-102.
18. Udonsi JK. The status of human filariasis in relation to clinical signs in endemic areas of the Niger Delta. Annals of Tropical Medicine and Parasitology. 1986: 80(4), 425-432.

19. Braide EI, Ikpeme B, Edet E, Atting I, Ekpo UF and Kale OO. Preliminary observation on the occurrence of lymphatic filariasis in Cross Rivers State. Nigeria Journal of Parasitology. 2003: 24, 9-16.

20. Amadi CA and Udonosi JK. Filariasis in Ogoni land: species diversity, prevalence and intensity of infection. Book of Absract, Nig. J. Parasit. 2004, 91.

21. Dogara M, Nock H, Agbede R and Ndams I. Hydrocelectomy as an indicator for the occurrence and spread of lymphatic filariasis in Kano State, Nigeria. The international Journal of Tropical Medicine. 2012a: 8(1), 16.

22. Ladan MU, Tukur AT, Moyi SI. Seroprevalence of lymphatic filariasis in six communities of Bungudu Local Government Area, Zamfara State, Nigeria. Int.J.PureApp.Biosci. 2018: 6(3), 11-18.

23. McCarthy J. Diagnosis of lymphatic filarial infection. In: Lymphatic filariasis Nutman, TB Ed; 2000: 1, 127-150.

24. Michael E, Bundy DA and Grenfell BT. Reassessing the global prevalence and distribution of lymphatic filariasis. Parasitology Today. 1996: 112, 409-428.

25. Ramaiah KD, Kumar KN, Ramu K, Pani SP and Das PK. Functional Impairment caused by lymphatic filariasis in rural areas of South India. Journal of Tropical Medicine and International Health. 1997: 2(9), 832-838.

26. Ramaiah KD, Das PK, Michael E and Das PK. The economic burden of lymphatic filariasis in India. Parasitology Today. 2000: 16(6), 251-253.

27. Edungbola LD. Babanaparasitics disease project II. Prevalence and impact of dracuntiasis in Babana District of Kwara State, Nigeria. Trans. Roys.Soc.Trop.Med.Hyg. 1983: 77, 310-315.

28. Subra R. Distribution, bionomics and control of Culex pipiense quenquifasciatus as vector of Wuchereria bancrofti. 
WHO/FIL/EC/WP/83-93, WHO Geneva; 1983.

29. Fonseca DM, Smith JL, Wilkerson RC and Fleischer RC. Pathways of expansion and multiple introductions among worldwide populations of the southern house mosquito. American Journal of Trop.Med and Hyg. 2006; 74 (2), 284-289.

30. Lapointe DA. Dispersal of Culex quinquefasciatus (Diptera: Culicidae) in Hawaiian rainforest. J.Med.Ent. 2008; 45(4), 600-609.

31. Machtinger ET, Leppla NC, Hogsette JA. An assessment of the seasonal abundance and species composition of filth flies on equine facilities. Journal of integrated pest management. 2015; 6:16.

32. Eberhard ML and Lammie PJ. Laboratory diagnosis of filariasis. Clin. Lab. Med. 1991: 11, 977-1010.

33. Chandrashekar R, Curtis KC, Ramzy RM, Liftis FLBW and Weil GJ. Evaluation of a recombinant antigen-based antibody assay for diagnosis of bancroftian filariasis in Egypt. Mol. Biochem. Parasitol. 1994: 64, 261-271.

34. Amaral F, Dreyer G, Figueredo JS, Norões J, Cavalcanti A, Samico SC, Santos A and Countinho A. Adult worms detected by ultrasonography in human bancrofti filariasis. Am. J. Trop. Med. Hyg. 1994: 50, 753-757.

35. Rocha A, Lima G, Medeiros Z, Santos A, Alves S, Montarroyos U, Oliveira P, Beliz F, Netto $M$ and Furtado A. Circulating filarial antigen (CFA) in the hydrocele fluid from individuals living in bancroftian Area-RecifeBrasil, detected by the monoclonal antibody Og4C3-assay. Mem. Inst. Oswaldo. Cruz. 2004: 99, 101-105.

36. Brooker S. Estimating the global distribution and disease burden of intestinal nematode infections: adding up the numbers-a review. Int. J. Parasitol. 2010: 40, 1137-1144.

37. Bartsch SM, Hotez PJ, Asti L, Zapf KM, Bottazzi ME and Diemert DJ. The global economic and health burden of human hookworm infection. PLoS. Negl. Trop.Dis. 2016: 10, 0004922.

38. Murray CJL, Ezzati M, Flaxman AD, Lim S, Lozano R and Michaud C. Years lived with disability (YLDs) for 1160 sequelae of 289 disease and injuries 1990-2010: a systematic analysis for the Global Burden of Disease Study 2010. Lancet. 2012: 380, 2197-223.

39. Salomon JA, Haagsman JA, Davis A, de Noordhout CM, Polinder S, Havelaar AH. Disability weights for the Global Burden of Disease 2013 study. Lancet. Glob. Health. 2015: 3, 712-723.

40. Dreyer G, Amaral F, Noroes J, Medeiros Z and Addis D. A new tool to assess the adulticidal efficacy in vivo of antifilarial drugs for Bancroftifilariasis. Transaction of the Royal Society of Tropical Medicine and Hygiene. 1995: 89, 225-226.

41. Yahaya UA, Mukhtar MD and Sa'adatu H. Epidemiology of lymphatic filariasis in Danbatta and Kumbotso Local Government Areas of Kano State, Nigeria. Int. J.Science and App.Research. 2016: 26(1), 364-371.

42. Dogara M, Nock H, Agbede R, Ndams S and Joseph K. Prevalence of lymphatic filariasis in three villages in Kano State,Nigeria. The Internet Journal of Tropical Medicine. 2012b $8(1), 1-8$.

43. Wijeyaratine PM, Singhai P, Verma OP and Motha B. Transaction of the Royal Society of Tropical Medicine. 1982: 76(3), 387-391.

44. Engelbrecht F, Tobias O, Ursula H, Claudia L, Diana O, Henry EP and Kaliraj FE. Analysis of Wucherirabancrofti infections in village community in Northern Nigeria: Increase Prevalence in individual infected with Onchocercavolvulus.Parasitology

International. 2003: 53, 13-20.

45. Anosike JC, Onwuliri COE and Onwuliri VA. Human filariasis in Das local government area of Bauchi state, Nigeria. International society for Tropical Ecology. 2003: 44(2), 217-227.

46. Elkanah OS, Elkanah DS, Madara AA, Akafyi DE, Kela S, Anyanwu G and Samaila A. Rapid Epidemiological Assessment of lymphatic filariasis in Northern Taraba Focus, Nigeria. International Journal of Infectious Disease and Therapy. 2018a: 3(1), 6-12.

47. Elkanah OS, Elkanah DS, Wahedi JA, Samaila AB, Kela SL and Anyanwu GI. Clinical and parasitological studies in Jalingo 
LGA, Tarabastate,Nigeria. Asian Journal of Medicine and Health. 2017: 6(1), 1-7.

48. Elkanah SO, Swemwua TC, Elkanah DS, Madara AA, Kela SL, Samaila AB, Bingbeng JB and Ishuwa MN. Status of lymphatic filariasis in five communities of Yorro Local Government Area, Taraba State, Nigeria. Nigeria Journal of Parasitology. 2018b: 39(1), 42-47.

49. Badaki JA, Akogun OB, Motta NB and Imandeh $\mathrm{G}$. Bancroftiasis among the mumuye of Northeastern Nigeria: Parasitological and Clinical Studies in Northern Taraba state. Health. 2013: 5(1),138-142.

50. Agbo OE and Ochanya J. Clinical epidemiology of lymphatic filariasis and community practices and perceptions amongst the Ado people of Benue state, Nigeria. Afri.J.Infec.Dis. 2011: 5(2), 47-53.

51. Amaechi EC, Ohaeri CC, Ukpai OM, Ukoha KU, Nwachukwu PC, Ejike BU. Prevalence and clinical aspects of Wucherirabancroftiamong inhabitants of a resource limited irrigation project community, North Central Nigeria. Asian Pac.J.Trop.Dis. 2017: 7(1), 32-35.

52. Terranella A, Eigiege A, Gontor I, Dagwa P, Damishi S, Miri E, Blackburn B, McFarland D, Zingeser J, Jinadu MY and Richards FO. Urban lymphatic filariasis in central Nigeria. Annals of Tropical Medicine and Parasitology. 2006: 100(2), 163-172.

53. Ufomadu GO, Nwoke BEB, Akoh JI, Sato Y, Ekejindu GOC, Uchida A, Shiwaku K, Tumbau M and Ugomo KK: The occurrence of loasis, mansonellosis and wuchereriasis in the Jarawa River Valley, Central Nigeria. ActaTropica; 1991: 48, 137-147.

54. Christiana O, Olajumoke $\mathrm{M}$ and Oyetunde. Lymphatic filariasis and associated morbidities in rural communities of Ogun State, Southwestern Nigeria. Travel medicine and Infectious Disease. 2014: 12, 95-101.

55. Ojurongbe O, Akinbo JA, Ogiogwa IJ, Bolaji OS and Adeyeba OA. Lymphatic filariasis in a rural community in Nigeria, a challenge ahead. Afr.J.Med.med.Sci. 2010: 39, 179-183.
56. Okorie PN, Davies E, Ogunmola OO, Ojurongbe O, Saka Y, Okoeguale B and Braide EI. Lymphatic filariasis baseline survey in two sentinel sites of Ogun sate, Nigeria. Pan African Medical Journal. 2015: 20, 397.

57. Adekunle NO and Asimiea AO. Prevalence of lymphatic filariasis and Associated clinical morbidities among Adolescent in three rural communities in Ondo State, Southwest Nigeria. J Trop Med Health. 2018: 2,120.

58. Adekunle NO, Sam-Wobo SO, Adekunle MA, Ekpo UF, Davies E and Surakat OA. Prevalence and sistribution of Wucheririabancroftiin Ose local government area, Ondo state, Nigeria. Nigeria Journal of Parasitology. 2016: 37(1), 96-100.

59. Brant TA, Okorie PN, Ogunmola O, Ojeyode NB, Fatunade SB, Davies E, Saka Y, Stanton MC, Molyneux DH, Stothard JR and KellyHope LA. Integrated risk mapping and landscape characterization of lymphatic filariasis and loiasis in South West Nigeria. Parasite Epidemiology and Control. 2018: 3, 21-35.

60. Manafa OU, Awolola TS, Idowu ET, Adedoyin JA and Adeneye AK. Epidemiological mapping of lymphatic filariasis in Southern Nigeria: Preliminary survey of Akinyele local government area. African Journal of Clinical and Experimental Microbiology. 2004: 5(3), 231-234.

61. Amaechi EC. Lymphatic filariasis among the Ndoki people of Ukwa East local government area, Abia state Eastern Nigeria. Nigeria Journal of Parasitology. 2014: 35(1-2),83-88.

62. Ivoke NJ, Ezeabikwa BO, Ivoke ON, Ekeh FN, Ezenwaji NE, Odo GE, Onoja US and Eyo JE. Wucherirabancroftiinfection in rural tropical guinea-savannah communities: Rapid epidemiological assessment using Immunochromatographic card test and prevalence of hydrocele. Tropical Biomedicine. 2015: 32(2), 365-375.

63. Kalu NK, Alaribe AAA and Shoniron OT. Using clinical signs to determine the endemicity level of lymphatic filariasis in Afikpo North LGA, Ebonyi state. 
Global.J.Bio-Sci and Biotecnology. 2013: 2(4), 554-559.

64. Ojiako OA and Onyeze GOC. Epidemiological and biochemical studies of human lymphatic filariasis and associated parasitoses in Ogun, South-Eastern, Nigeria. African Journal of Biochemistry Research. 2009: 3(4), 114-119.

65. Udonsi JK. Filariasis in the Igwun river basin, Nigeria: an epidemiological and clinical study with a note on the vectors. Annals of Tropical Medicine and Parasitology. 1988: 82(2), 7582.

66. Itina VI, Noutcha AE and Okiwelu SN. Wuchereriabancroftiinfection rates in humans (Vertebrata:Hominidae) and Mosquitoes (Diptera:Culicidae), Akwalbom state, Nigeria. Research in Zoology. 2014: 4(1), 1-7.
67. Agi PI and Ebenezer A. Observation on Filarial infection in Amassoma Community in the Niger Delta, Nigeria. J.Appl.Sci.Environ.Manage. 2009: 13(1), 1519.

68. Okon OE, Iboh $\mathrm{CI}$ and Opara KN. Bancroftianfilariasis among the Mbembe people of Cross River state, Nigeria. J. Vector Borne Dis. 2010: 47, 91-96.

69. Iboh C, Okon OE, Opara KN, Asor JE and Etim SE. Lymphatic filariasis among the Yakurr people of Cross River state, Nigeria. Parasites and Vectors. 2012: 5, 203.

70. Nsima IU, Braide EI, Nnamdi K, Atting I and Adie HA. Current status of bancroftian filariasis in rural communities of the lower cross river basin, Nigeria: Parasitological and Clinical aspects. J.Pub.Health. 2008: 16(6), 383-388. 